\title{
Approach to the Social and Political Problems of Female Agricultural Labourers
}

\author{
Dr. Sanjay Babu \\ Assistant Professor, P.G. Departmentt of Commerce, \\ M.G.M. (P.G.) College, Sambhal, Uttar Pradesh, India
}

\begin{abstract}
The idea of a person is both the motivator and the result of his/her behavior. To study the behaviour of a person. It is necessary to know his/her throughts and attitudes, his/her thinking and ideology. In the research paper presented from this perspective, it is also necessary to get knowledge of their thoughts and attitudes in order to gain knowledge of different situations and problems of life of female agricultural labourers. Attempts were made to see that the appropriate age of bridegroom at the time of marriage of female agricultural labourers, their attitude in realtion to inter-cast-marriages, her thoughts regarding dowry practice include her involvement in the family decisions of family and her views towards the social practices related to the marriage, family and dowry. In the current society socio-economic, political, educational and cultural fields are changing repidly.
\end{abstract}

In the present period of female education, female awarners and female's movement and progressive and modernization, the female agricultural labourers are still the nutritionals of conservative ideas and attitudes or represent progressive ideas. This research paper is an attempt to study attitude of the female agricultural labourers.

KEYWORDS: Social, political, problems, female, agricultural, labourers, Traditional approach, progressive though.

\section{INTRODUCTION}

Ancient India, the prevalenece of child marriage was that the bride's age at the time of marriage was very low, but the current legal, women education spread by the government iinthe present time was due to the the influence of western culture but in the rural areas this practice is still practiced somewhere. So in this regard, it is necessary to known what is opinion of female agricultural lebourers in relation to the child marriage? According to tradition and practice in the rural surroundings, child marriages of most female labourers were concluded, which were about 12 to 15 years of age. In the study of Shobha, most of female labourers were less than 15 years of age at the time of marriage, According to the 2011 census, one million girls in India get married before the age of 18 .

In the case of child marriage in India there has been a decrease iin the last 10 years. 10 years ago child marriage was $47 \%$ which has now reduced to only $27 \%$ World Wide the rate of child marriage has decreased from $50 \%$ to $30 \%$. This result has come from UNICEF's report on child marriage. The most of female labourers have been below the expected age of 18 years at the time of marriage. In this context, it is also worth mentioning that at least 21 for mens at least 18 for women, prescribed for marriage by the government. Thus, anticipated age of female labourers falls under the category of child marriage. Therefore, it is also important to know about the age of marriage of the child marriage, in the context of woman entering the family life, in which age would they like to marry their children?

In this regard, the expected age of youth was less than 21 years by most of the female agricultural labourers and girls below 18 years of age were found suitable. It is worth mentioning have that most of the female labourers whose percentage is 90 is less than 17 years at the time of marriage, which falls under the children's marriage. As a conclusion, it can be said that the idea of female labourers in the age of mariage at the time of marriage in most cases both bride and groom. Therefore, in the presented research paper, a conjecture of the study is confirmed by the idea of female agricultural labourers in the context of the age of marriage is conservative.

In India, it is suggested to promote Inter caste marriages to avoid the consequences of caste system or eliminate racism. In the context of modernization, marrying in its own caste is a traditionalist practice and inter caste marriage is considered as progressive and modern practice. Therefore, it is also important to know what extent female agricultural labourers accept inter cast marriages in the presented research paper. Is the idea of inter cast marriage appropriate? In relation to inter cast marriage, in mass of female agricultural labourers, whose $\%$ is about $90 \%$ is the protest against the inter cast marriage system. It is clear from this that her views are conserratives in this regard.

The prohibition of widow remarriage has been a serious problem of Hindu Society. In today's society, social and cultural conditions are changing, but remarriage of widow in rural areas is not so simple and easy. Therefore, It is necessary to know the attitude of female labourers in this regard. Most of female labourers do not consider widow remarriage appropriate. Very few female labourers hold their thoughts, In favour of widow remarriages. It is clear from this that in this regard, the idea of female labourers are still conservative and traditional.

In ancient times, marriage was accepted as a sacred religious sites, it was believed that marriage is a bond set by God, which can not be broken down to life death itself can break it. Thus was believed in the uninterrupted nature of the marriage, but the current socio-cultural conditions have 
brought immense changes in this notion of the marriage. Accordingly marriage is accepted as a contract. If the contract is not welfare. For both parties then it can be broken. What is the Idea of female agricultural labourers in this regards, it is also resonable to know? Most of female labourers do not consider marriage breaks to be reasonable, whose $\%$ is $65 \%$. In these areas, these female labourers hold conservate views. Nearly $35 \%$ of female labourers have an attitude in favour of marriage breaks, more than one third. This way awareness of them is coming from this, progressive future can be imagined.

Most of the female labourers have supported the acceptance of child marriage and dowry system in a proper manner. Seeing so much support of these two practices by the female labourers in the present society, this idea arises in the mind of that it is not so that female labourers are not aware of the social laws created against these mischief. In relation to child marriage Preventive law and dowry prevnetion Act, there is not much knowledge of female agricultural labourers while about 35\% female agricultural labourers have knowledge of anti dowry Act and child merriage prevention Act. It is known from that most of female labourers do not have the knowledge of these Acts. Along with this, one more thing hasa been noticed, those who have knowledge also do not want to comply it. It is a symbol of their conservative attitude.

In ancient Indian society joint and large size families were found, but in the present soceity, the prevalence of system and small size families has increased. In this regard, most female agricultural labourers, whose percentage is 70, clear from the idea that alone family syste $m$ is justified, similarly, in relation to the expected size of the family and the number of expected children, most of the female agricultural labourers accept the proprtion of the three children, properly acceptiing small size families. Thus, the idea of female labourers in relation to the concept of family is influenced by modernity.

In the context of husband wife relations before independence the situation of female was very pitiable. In the context of their inter personal relations, the wife was considered as a slave and a second class citizen. In family decisions they were not consulted and discussed. Manu hasa said that the husband should be treated like God, Whether he is a man without a clean person and all his virtues! Yagvlakay said that wife should obey the commands of their husbands. This is their biggest religion. Thus, in the ancient times, the status of female in family life was lowest, but at present, there has been a lot of change in the situation of female. In relation to husband and wife relations, Mahatma Gandhi said that the wife is not the maid servant she is a half siter co-consort, she shold be considered as a friend. In this situation, in the present scenario, there has been a change in the present time but it is very important to know how much the rulal females and the female agricultural labourers are affected by it. This is a female group of rural society who is playing an active role in the economic upliftment of the family. Therefore it is believed that their thinking must have been influenced and they will have a decisive role in the family. Therefore it is very important to know two things, first what is the nature of relationship between husband and wife and second, sould female be consulted in family decisions? In relation to the relationship of husband \& wife, most of the female agricultural labourers still regard the relationship between the husband and the wife as the only relationship between God and maid. The remarkable fact is that only $10 \%$ of the female agricultural labourers have imagined the same relationship between and male and a female. It is evident from the fact that most of his sayings on husband wife relations are still at the traditional level. Yes, there has come to be so much difference that their thinking has come at the level of relationship God \& maid in place of high \& low, whose percentage is 40 , But to get the level of equality, she has not been able to make mentality even today.

Most of females are concerned about female's decisions and counse ling in family decisions that females should be consulted in family decisions. She is not interested in establishing equality with male but because she is earning herself, therefore she considers her involvement in family decisions as necessary. That is, about $20 \%$ of the female labourers in this area have a mental attitude that if a female is involved in economic participation then her family should have a decisive role because she can understand the problems of family in a timely manners only $2 \%$ of female labourers are still so backward that they hold this view that the right to male decisions regarding family is only for make and there is no need to consult them. It is probably the result of their awareness that the majority of studies are discussed in family decisions from the majority of female. Regarding the money to be spent on dowry and other items in $85 \%$ households, and $68 \%$ of households, husbands and wife together decide on the sales purchase of movable immovable property. It is also evident from the study that in $80 \%$ of the households, decisions regarding the age of marriage of children and selection of bridge groom are taken by female themselves. It is thus clear that in the relationship between husband and wife, the impression of God and highly recognized to her husband has not yet ended, but they taking part in family decisions, husband and wife are highly aware of equality in practical life, Because, in relation to their participation in family decisions, $89.2 \%$ of female labourers are positive in anticipation of that, $75.4 \%$ have also accepted that their participation in family decisions remains. Along with this the effective participation of female labourers in the decision making of the dowry, sales purchase of movable immovable property and the age of marriage of the children and the choice of bride groom is certified.

The influence of religion and tradition was very high in ancient Indian society. Religions and religious beliefs were people's faith and people were fatal, but the influence of religion practice, tradition etc. is decreasing in the present society. Ancient beliefs, ideals and values are being rejected in society.

In the research paper the idea was deemed necessary to know the practices, traditions religion and the fate of female agricultural labourers. Mostly female agricultural labourers believe in God's power. On acqruiring about the practical form of their expression of faith in God, it is known that most of the female agricultural labourers do worship and they have tendency of performing daily worship and prayer, whose percentage is $82 \%$ very few female labourers do not believe in God's power. Thereforer, it is clear that most of female agricultural labourers believe in God \& religion, and by them the worship of this faith isi expressed through pooja or prayer. 
In addition to religion, the practice and traditions in ancient India have also been of utmost significance in social life, althrough modern India's advance towards modernization has decreasing the effect of the practice, traditions and religion, but in rural society it still has its feet. So it is also important to know how much female agricultural labourers believe in traditional beliefs in situals and situals and in what ways do they want to adopt these traditional beliefs and ideals? Whether or not in earlier times. Most of female labourers want to adopt earlier whose percentage is 60.4 and 37.6 percentage of female labourers want to adopt them on time. Only 2 percentage female agricultural labourers do not want to adopt them.

In relation to the belief in traditional rites and rituals, mostly female agricultural labourers believe in this, whose percentage is $87.4 \%$. Only $12.6 \%$ female labourers do not believe in traditional rites and rituals. Therefore, it is evident from the above figures that their views on traditional beliefs and traditional rituals and rituals are traditional and they have never been influenced by modernity. Relgion was believed in Indian, Indian culture that whatever happens in the person's life is the result of his destiny, that is earlier people were very fatal, but due to the decreasing influence of religion and the importance religion in the presently changed socio-cultural conditions, people started giving importance to their efforts in place of fate. In this regard, it was considered necessary to obtain this information from the female agricultural labourers that what is the basis of important events of their life-their fortune or their efforts? Most of female agricultural labourers, whose percentage is 76 are still fatal. In her view, all the events of life happen only according to fate, destiny is created by God, so he can make changes in the same. In this way it can be said that most of female agricultural labourers believes in their traditions, in religion and fate and it is also conservative because of relgions beliefs and for being fatal.

Education is the cornerstone of the development of a person and society. The need for education is not only in certain areas, but there is an important role of education in every area of life and in activity. Therefore, the concept of compulsory education in the current soceity is becoming strong. So it is also important to know what the female agricultural labourers think about education? At present, the majority of the female agricutural labourers accept the compulsory and usefulness of education, whose percentage is $89.6 \%$ only $10.4 \%$ female agriculture labourers do not accept the inevitability of education.

It is thus clear that the idea of female agricultural labourers in progress the current life is progressive. It is also necessary to know here that what is the idea of female labourers towards female education?

Because in ancient India female education has been prohibited, althoughs today the promotion of female education in the country is increasing repidly, but the truth is that there is a negative attitude towards education, in rural areas it is also important to know look at the evaluation of ideas of female and especially in the female labourers coming in. They change their ideas in the form of work. Mostly female agricultural labourers have awareness of education, due to which they believe in the notion of compulsory education and most of the children also go to school. Now another question arises here whether it is mandatory for both boys and girls to get education and whether it is the expectation of girls to run education at the same level at which level boys want to teach?

In relation to the educational level of the son and daughter, most of female labourers hold the expectation of their son to graduate and high and business level and do not want to be uneducated them. Female agricultural labourers, where there are high educational expectation for their son, their expectations for the education of daughters are influenced by traditional thinking. In the absence of awareness, about $20 \%$ female agricultural labourers still want to keep their daughters uneducated. Very few female labourers want to teach their daughter till graduation. There is also a remarkable fact that no female labourers expect their daughters to get post graduate or professional education most of female Agricultural labourers have accepted the inevitability of education whose percentage is $85 \%$ but it appears that the need for education in terms of possibly a men's class. Therefore for their sons, their educational expectations are high while their daughter's have low for them. It can be said that in order to educate men, there is much higher ambition than the daughter in the female agricultural labourers. That is they have negative tendency towards female education. Conclusion :

On the basis of prior consideration related to the views and views of female agricultural labourers, it can be said that she supports child marriage. Most of them had a child marriage and in the context of their offspring, they still have anticipation of child marriage. Regarding Inter caste marriage, it is seen that they do not like Inter Caste Marriages. Regarding widow remarriage, it is obvious that they do not consider remarriage of widows as appropriate. Nearly two third female labourers are against the marriage breaks Mostly female labourers consider Dowry practice as appropriate and necessary. As far as the child marriage prevention. Act and Anti Dowry Act are concerned, a large number of female agricultural labourers do not have this knowledge. It may be said that the concept of child marriage, widow remarriage, dowry and Inter Caste Marriages is still conservative as the idea of female agricultural labourers. Most of female labourers do not vote in opposition to the justification of marriage breakdown but the inclination of one third of the female agricultural labourers is in the direction of accepting its justification. In this way, it can be said altogether that although in relation to all these problems, traditions display the views of the pedestrians, but their views are moving forward towards the progressive direction.

From her thoughts in relation to the family, it is known that most of female labourers have considered the lonely family arrangement as proper. Like wise, on finding the number of candidates, most of female labourers accept the expectation of three offspring and accept the small size familifes properly. In this way their thoughts regarding the structure and size of the family are influenced by modernity. In the case of reciprocal relations of husband wife, it is seen that mostly female agricultural labourers have anticipated the relationship between husband and wife between God and maid. Similarly in relation to the counseling of women in family decisions, it is seen that the idea of most of female labourers should be consulted in family decisions. It is seen that they are also aware of it and the result of this awareness is that most of female labourers are consulted in family 
decisions. If is often seen that in most families, both husband and wives take part in the decision to dowry other exp., and to buy or sell of movable and immovable property. The most notable fact in this regard is that in most of the families the decision of the age of the marriage of the children and the decision of the bride groom is taken by the female herself and she playes a decisive role.

From their thoughts in relation to tradition and religion, it is known that in the form of practical expression of faith in the power of God, most of the female labourers the tendency of worship and prayer etc is found in them. Traditional beliefs in relation to the beliefs of rites, it is seen that most of female labourers like traditional beliefs like preceding them, they have unawavering devotion. A part from the most of ideas and rituals situated were related to tradition. In relation to their approach towards life events. It is seen that most the female Agricultural labourers are still fatal today. In her view, all the events of life happen according to fate.

The concept of compulsory education is becoming strong today. As it understands the cornerstone of education society and person. In this regard, it is known from her views that most female agricultural labourers accept the compulsion of education.

\section{References}

[1] Acharya, Meena Benett Eyam: Woman and the subsistence sector Economic participation and household.

[2] Bannerjee Nirmala: Women Workers in the unorganised Sector, Savfaue Proote, Hyderabad.

[3] Bhardhan Kalpana : Stratification of Women's work in Rural India Determinants, Effect and strategies in Dilip K. Baser richarts Sissions.
[4] Charkravarty, Shanti: Farm women labour waste and exploitation social charge - V-5 (1-2) 1975.

[5] Chaterjee, B.B.: Impact of social Legislation on social change, Minerva, Caluctta 1971.

[6] Dasgupta, Biplav: Village society and Labour use, Oxford university press, Delhi, 1977.

[7] Dasgupta Swapan: Feminism and struggle for socialism : Revies Article, Economic and political weekly Vol. XV, No. 5, December 27, 1980.

[8] De Souza, Alfred: Women in contemporary India, Manohar Publications, New Delhi, 1975.

[9] De Souza, V.S.: Family Status and female work participation; An Emperica; Analysis, Social Action, 25, No.3 July September, 1975.

[10] Devdas R.P.: Role of women in Modern Agriculture, India farming, Vol. XXV, No.8, Nov. 1975.

[11] Gulati, Leela: Profile of female Agricultural, Labour, Economic and political weekly (supplement) 13 (12) 25th March 1978.

[12] Hiranand and kumar, K.: Role of farm women of Dry farming tract in Decision making, India cooperative Reivew, WVII, Jan, 1980

[13] Kapur, promilla: Marriage and the working women in India, Delhi, 1970.

[14] Mencher J.:women's work and poverty women's contribution to house hold maintenance in south India.

[15] Nath, K.: Women in the work force in India: Economic and political weekly, III August, 1968.

[16] Nischol, K.: Rural women, their rights, Status and problems, Social welfare, 21(II), February, 1975.

[17]/Dainik Bhasker March 7. 2018 